\title{
RESEARCHING PRACTICES IN LITERACIES ACROSS LANGUAGES AND SOCIAL DOMAINS: INTERNATIONAL PERSPECTIVES
}

\section{Paula Tatianne Carréra Szundy ${ }^{*}$ Maria Lucia Castanheira** Judith Green ${ }^{* * *}$}

In the book on Re-theorizing Literacy Practices edited by Bloome, Castanheira, Leung \& Rowsell (2019) is the following quotation grounded in the work of Brian Street that represents a critical definition of literacy practices central to the papers presented in this special issue of Trabalhos em Linguistica Aplicada/Papers in Applied Linguistics focusing on Researching practices in literacies across languages and social domains: International Perspectives.

Literacy practices are not just abstract cultural models held in people's minds but are embedded in all aspects of the social situation (i.e., in the physical environment, in how people act and react to each other, etc.) (BLOOME cited by Rhoades, 2019, p.xiv).

This quotation captures the view of literacy/literacies as social practices of our editorial team, who are co-coordinators of the Research Network (ReN) on Literacies Across Languages and Social Domains". This ReN was proposed to the International Association of Applied Linguistics (AILA) and was formed in 2018. The roots of this ReN are grounded in international dialogues about literacies at the AILA Conference in 2017 in Rio de Janeiro and in dialogues with international scholars from previous AILA meetings $(1999 ; 2005,2008)$ - (e.g., Luis Paulo da Moita Lopes, Marilda Cavalcanti, David Bloome, Brian Street, among others).

Given the meaningful dialogues that applied linguists across national contexts have been establishing with concepts in the field of literacy studies, the

\footnotetext{
* Federal University of Rio de Janeiro, UFRJ, Rio de Janeiro, Brazil. ptszundy@letras.ufrj.br

Orcid: https://orcid.org/0000-0001-8465-1406

** Federal University of Minas Gerais, UFMG, Belo Horizonte, Minas Gerais, Brazil. lalucia@gmail.com Orcid: https://orcid.org/0000-0003-4839-9682

*** University of California Santa Barbara, Santa Barbara, California, the United States. judith. green@gmail.com

Orcid: https://orcid.org/0000-0002-3379-6733

1.For further information about AILA's Research Network on Literacies Across Languages and Social Domains, access https://aila.info/research/list-of-rens/literacies-across-languages-and-socialdomains/. In case you are interested in joining this $\mathrm{ReN}$, send an e-mail to one of the convenors.
} 
ReN aims at bringing together international scholars to develop a comprehensive view concerning the ways of studying literacy practices and processes in the scope of Applied Linguistics. As this volume will demonstrate, scholars who are part of this ReN draw on and explore different perspectives on language and literacy relationships in multiple social spaces and/or institutions, including New Literacy Studies, multiliteracies, digital literacies, academic literacies, interactional ethnography, among others.

This special issue results from an open call for papers on researching literacy processes and practices developed in and through various languages (e.g., Chinese, English, Portuguese, Spanish, among others) and social actions undertaken by particular configuration of actors in different social spaces (e.g., rural communities, higher education classes, academic writing collaborations, and K-12 classrooms, etc.). This special issue, therefore, brings together authors whose research perspectives (i.e., epistemologies, ways of knowing, e.g., KELLY, 2006) add new insights into ways of studying the multi-faceted, dynamic, complex, and discursive nature of literacy processes, practices and texts in particular social, cultural, linguistic, and political spaces. These articles make transparent the decisions and epistemological actions taken by each author/team of authors to examine the consequences of complex literacy contexts (personal, policy, instructional, and institutional). Thus, the authors of these papers address questions of the following nature:

- How are ideologies and practices established within and beyond local groups that shape what counts as literacy processes and practices?

- How are processes and practices communicated to and developed by participants in particular social and educational contexts in and through language(s)-in-use?

- How do decisions made by particular actors within and across events in particular social and educational contexts (e.g., policy contexts, instructional contexts, and community contexts, among others) shape what is possible for participants to know, understand, do and accomplish in and through written, spoken and visual texts?

Thus, the questions addressed by different authors in this special issue, when considered together, provide a ground for understanding how local and more global meanings of literacy practices are (re)constructed and/or legitimized/delegitimized through discourses and interactions among participants in particular social contexts and educational systems. 
As the authors in this volume will make transparent ${ }^{2}$ through their diverse logics-of-inquiry, these issues have been addressed through multiple epistemological lenses across disciplines, languages and social domains. Therefore, the authors in this special issue of Trabalbos em Linguistica Aplicada/Papers in Applied Linguistics bring a broad range of epistemological approaches to this volume.

In establishing this special issue, therefore, we also sought to create opportunities for readers to engage in meaningful interactions with scholars from different national contexts and epistemological perspectives. To accomplish this goal, we asked the authors to make transparent their logic of inquiry, i.e., the roots of the problem, the theoretical perspectives guiding their processes of research, their methodological decisions, and processes of analyses. In this way, we sought to provide readers resources for tracing (i.e., re-constructing) the author(s)' epistemological approaches to identifying, exploring, theorizing and reporting complex interrelations of ideologies constructed at intersections of literacies and situated language uses in heterogeneous contexts and across social domains.

In this sense, each author/team of authors engages readers in exploring the particular epistemological and theoretical perspectives that guided their research processes and that framed often invisible dimensions of literacy impact on the lived experiences that shape what counts as literacy and languages-in-use for, and by, participants in particular social contexts. Through this approach to reporting the processes of their research, authors offer ways of examining how their research processes led to warranted accounts (HEAP, 1995; KELLY, 2006) and to understandings of the complex and consequential nature of language-literacy relationships in particular social settings. This volume, therefore, provides a rich and conceptually grounded space for (re)thinking what constitutes literacy studies in the scope of Applied Linguistics.

As readers engage with the papers in this volume, they will have opportunities to explore the potential of such research to enhance the understandings of what counts as literacy, and how literacies are socially constructed in the scope of Applied Linguistics. These papers will demonstrate how a multiplicity of perspectives results from fruitful dialogues that have been established within and across fields of study: Linguistics, Sociolinguistics, Discourse Analysis, Literature, Education, Cultural Studies, Sociocultural Theory, Conversation Analysis, Race and Gender studies,

2. The issue of transparency in reporting on research builds on Standards for Reporting on Empirical Social Science Research adopted by the American Educational Research Association (2006) to support readers in tracing the logic-of-inquiry of a published report, given the diverse perspectives and the challenges that they make for readers who do not share the same background or epistemological perspective. 
and Anthropology, among many others. On the one hand, the resignification of concepts from different fields to understand complex practices and processes that frame what is legitimated/delegitimated as literacies across social domains connects the contributions in this special issue to a transdisciplinary view of Applied Linguistics. On the other hand, the focus on how what counts as literacies is ideologically constructed (STREET, 1984) makes visible differential access across participants and social contexts.

According to Szundy and Fabrício (2019), the complex issues identified previously challenge traditional research cultures and epistemological routes by assuming a transgressive view of Applied Linguistics, which rejects interpretations that essentialize language, identity and contexts. By blurring the borders between disciplines/areas and opposing universal, functional and instrumental approaches to language studies, an INdisciplinary Applied Linguistics perspective aims at "comprehending our times and open spaces to alternative views or to listen to other voices that can reinvigorate our social lives or start comprehending them through other stories" (MOITA LOPES, 2006, p. 23) ${ }^{3}$.

The INdisciplinary view of Applied Linguistics is closely connected to the ideological model of literacies proposed by Street $(2009,2014)$. From both perspectives, there is no escape from ideology and, therefore, no possibility of assuming neutral perspectives towards situated language uses. Literacy practices, as Street reminds us, are always imbued of/by power relations, making it fundamental to comprehend how participants (re/de)construct meanings during and about literacy practices in which they engage from a socio-cultural perspective.

The 13 articles and review of the book on Las pedagogías de la comunidad a través de investigaciones locales en el contexto urbano de Bogotá (OLARTE; GALINDO, 2019) that compose this special issue both share an ideological perspective toward literacy and rely on multiple epistemological lenses to raise issues about meaning constructions and circulation processes of literacy practices in different social domains. These domains include educational, scientific, health, rural and digital spaces in Brazil, Taiwan, the United States, Mexico, and England. Collectively, these papers challenge conceptions that view language as a mirror and/or representation of reality. In contrast, they provide (de/re)constructions and refractions of languageliteracy relationships built through culturally and ideologically situated literacy perspectives. The interpretations of language-literacy relationships (re)presented

3. Our translation to "[...] compreender nossos tempos e de abrir espaços para visões alternativas ou para ouvir outras vozes que possam revigorar nossa vida social ou vê-la compreendida por outras histórias" (MOITA LOPES, 2006, p. 23). 
in the papers, therefore, focus on the hybrid and blurred nature of literacy practices, a process that can be understood through the concept of INdisciplinary (and transgressive) perspectives "which rely on mixtures and re-combinations as possibilities to reorganize social life" (SZUNDY, FABRÍCIO, 2019, p. 83).

In this volume, a primary focus of the papers is on literacy practices and processes in different educational contexts. These papers illustrate a conception of literacy emphasized by Freire and Macedo (2011 [1987]) that reading (and writing) the word require reading (and writing) the world. The borders between social domains, identity formulations, and speech genres are thus blurred so as to engage participants in situated language uses to (re)read and (re)write the social world. Focusing on elementary and secondary schools, the papers by Harris, Gupta, Tilio \& Lobo, Power-Carter, Mulico and Machado, Carvalho, Novais \& Rodrigues bring the following social domains into the scene:

- literacy encounters in which the reading abilities of a first-grade student is traced to challenge a school-based assessment of him as a non-reader (HARRIS),

- the tracing of dialogic processes between a fourth-grade teacher and the researcher that framed the collaborative design and implementation of a Content and Language Integrated Learning (CLIL) curriculum being introduced in a school in Taiwan (GUPTA);

- the production of transmedia pedagogical materials based on multimodal literacies to teach Spanish (TILIO \& LOBO) to secondary students in Brazili

- the issues of whose knowledge and prespectives count in complex social contexts of gender and racial identities by both Afro-Americans young women in a Literature class and the autobiographic experiences of the researcher in a family context in the USA (POWER-CARTER);

- the (multi)literacy practices triggered by the autobiography of a subaltern exlandless activist in which the teacher and students engage in a technical federal institute in the state of Rio de Janeiro, Brazil (MULICO); and

- the production of visual narratives about rural communities using short digital videos by youth from a rural school in Vale do Jequitinhonha, Minas Gerais, Brazil (MACHADO ET AL).

Literacy practices and processes through which social actors (de/re)construct knowledge in academic settings constitute the focus of Chian's, Szundy's, Dias'

4. Our translation to "[...] que apostam nas misturas e recombinações como possibilidades de reorganização da vida social" (SZUNDY, FABRÍCIO, 2019, p. 83). 
and Olmos-López \& Tusting's papers. Chian presents an interactional ethnographic analyses of how a design team led by an Organization Communication professor integrated long term and futures thinking with Organizational Communication theories in a Bachelor of Arts course of study in a public regional university in northern California (US). Szundy and Dias examine how freshman students of English in two public universities in the southeast of Brazil engage in meaningful academic writing practices. The genres that orient the literacy processes targeted by Szundy and Dias are learning autobiographies and abstracts. Also focusing on academic literacies, Olmos-López \& Tusting proposed ways that autoethnography supported their reflexive approach to examining the challenges of making transparent situated and institutional processes that supported and constrained their own journey as academic writers across countries (England and Mexico) and languages (English and Spanish). These papers also make transparent processes of (re)negotiating meanings involved in (re)writing abstracts (DIAS); (re)visiting language as well as engaging in mentoring relationships in which academic writers become both objects and subjects of their studies (OLMOS-LÓPEZ; TUSTING). In these processes, academic writing practices become spaces where professional identities and academic cultures can be destabilized.

Additionally, Mendez \& Kalman assume the ideological nature of literacies to challenge the normative regime of values that attribute more legitimacy to standardized scientific writings in contrast to those produced in a community citizen-science program in Mexico. The paper explores the production and circulation of reports on the migration of the monarch butterfly in Mexico produced by voluntary scientists so as to understand how the participants involved in the (re) writing processes resignify semiotic resources as meanings are recontextualized. Also emphasizing the central role of lay people in the co-interpretation of scientific knowledge, Ostermann, Frezza \& Perobelli analyze the interactional resources mobilized by health professionals and patients in the processes of interpreting fetal ultrassound images. While Mendez \& Kalman's and Ostermann, Frezza \& Perobelli's papers legitimate lay people's participation in scientific literacies, Martins examines the literacy practices in which fan fiction readers and writers engage in order to scrutinize the language ideologies (de/re)contextualized by participants in relation to what they see as standard Portuguese and literary canon.

In addition to the myriad of social spaces and languages in which literacy practices and processes are embedded as briefly described above, readers will have opportunities to interact with the interpretative epistemological approaches that the authors in this special issue developed. By (re)tracing the developing 
logic-of-inquiry of each author/team of authors, readers will have opportunities to examine how these authors engaged participants in their research in (de/re) constructing and/or (de)stabilizing local meanings of literacy and other semiotic processes. Sharing ethnographically oriented approaches to literacy studies, these epistemological perspectives provide readers with opportunities to interact with the knowledge about literacy practices produced in the articles in the light of the following questions proposed by Street (2009, p. 337):

- What is the power relationship between participants?

- What are the resources that participants draw on or construct in and through the in time and over time interactions in particular social contexts?

- What are the consequences for participants if they take a social (ideological) model of literacy rather than an autonomous model of literacy?

These questions may also be fruitful in addressing the review of the book that closes this thematic issue. In this review, Calderón-Aponte describes and reviews the conceptual and epistemological perspectives framing literacy studies in urban contexts presented in the book "Las pedagogías de la comunidad a través de investigaciones locales en el contexto urbano de Bogota" (Community pedagogies through local investigations in the urban context of Bogotá), edited by Amparo Clavijo Olarte y Luz Maribel Ramírez Galindo.

To support readers in gaining a comprehensive understanding of the issues raised across the articles in this special issue, given the diversity of social spaces and people studied by different authors, and the range of theoretical and epistemological perspectives guiding their work as researchers, we propose the following ethnographically-oriented principles adapted from the works of linguistic and social anthropologists Shirley Brice Heath and Brian Street, among others (GREEN; CASTANHEIRA, 2019). This process will involve readers in:

- Suspending their known categories to construct understandings of how the author(s) engaged in the study and (re)presentations of local and situated literacy processes and practices in particular social spaces for particular purposes;

- Acknowledging differences between what these researchers know and produced and what they have learned through their own research;

- Developing ways of exploring how the authors (re)presented what was known by local actors and what the researchers learned from the analysis at different levels of analytic scales as (re)presented in their warranted accounts. 
Through these principles, readers will have the opportunity to trace the logicof-analyses that these authors developed to examine and (re)present warranted accounts of the ways in which particular configurations of participants in diverse social spaces constructed literacy processes and practices that were consequential for their everyday lives. By reading across the papers, therefore, readers will be able to engage with, and critically examine, the theories and methodological decisions made by each author/team of authors and to examine the literature that each drew on to support and/or challenge autonomous (STREET, 1984) views of literacy. We hope that the dialogues with heterogeneous research practices in literacies across languages and social domains presented by the authors of this special issue will enhance understandings of, and shed light on, the emerging set of epistemological approaches to literacy practices that are developing at the intersection of literacy studies and Applied Linguistics.

\section{REFERENCES}

BLOOME, D.; CASTANHEIRA, M.L.; LEUNG, C; ROWSELL, J. (2019) (Eds). Rethinking literacy practices Complex social and cultural contexts. New York/London: Routledge.

FREIRE, P.; MACEDO, D. (2011). Alfabetização: leitura do mundo, leitura da palavra. São Paulo: Editora Paz e Terra.

FREIRE, P.; MACEDO, D. (1987). Literacy: Reading the word \& the world. Westport, CT/ London: Bergin \& Garvey.

GREEN, J.; CASTANHEIRA, M. (2019). Revisiting the relationship between ethnography, discourse and education/Revisitando a relação entre etnografia, discurso e educação. Caletroscópio, 7, p. 10-55.

HEAP, J. L. (1995). The status of claims in "qualitative" educational research. Curriculum Inquiry, 25(3), 271-292.

KELLY, G. J. (2006). Epistemology and educational research. In GREEN, J; CAMILLI, G., ELMORE, P. (Eds.). Handbook of complementary methods in education research. Mahwah, NJ: Lawrence Erlbaum, P. 33-55.

MOITA LOPES, L. P. (2006) (Org.). Por uma Linguística aplicada indisciplinar. São Paulo: Parábola. 
RHOADES, M. (2019). Artist's state on the cover. In BLOOME, D; CASTANHEIRA, M.L; LEUNG, C.; ROWSELL, J. (Eds.), Re-tbinking literacy practices Complex social and cultural contexts. New York/London: Routledge, p. xiv.

STREET, B. V.(1984). Literacy in theory and practice. Cambridge, UK/ Cambridge University Press.

STREET, B. (2009) Ethnography of writing and reading. In Torrance, N.; Olson, D. R. (Eds.) The Cambridge handbook of literacy. Cambridge University Press, p. 329-345.

STREET, B. (2014). Letramentos sociais: abordagens críticas do letramento no desenvolvimento, na etnografia e na educação. Trad. de Marcos Bagno. São Paulo: Parábola Editorial.

SZUNDY, P. T. C.; FABRÍCIO, B. F. (2019). Linguística Aplicada e indisciplinaridade no Brasil: promovendo diálogos, dissipando brumas e projetando desafios. In SZUNDY, P. T. C.; TILIO, R. (Orgs.) ; MELO, G. C. V. (Org.) . Inovações e desafios epistemológicos em Linguística Aplicada: perspectivas sul-americanas. 1. ed. Campinas: Pontes Editores.

Recebido: 23/03/2020

Aceito: 31/03/2020

Publicado: 31/03/2020 